\title{
THE ROLE AND PLACE OF FICTION IN TEACHING FOREIGN LANGUAGES AT NON-LINGUISTIC FACULTIES
}

\author{
Irina Meshkova ${ }^{1}$, Olga Sheremetieva ${ }^{2}$, Larissa Spynu ${ }^{3}$ \\ ${ }^{1}$ Assoc Prof., PhD RUDN University, RUSSIA, meshiran1@gmail.com \\ ${ }^{2}$ Senior Lecturer RUDN University, RUSSIA, oasher@mail.ru \\ ${ }^{3}$ Assoc Prof., PhD RUDN University, RUSSIA, lorance@rambler.ru
}

\begin{abstract}
Knowledge of foreign languages is an integral feature of the modern global world. One of the sources of information is still reading, in particular, reading fiction. The program of studying foreign languages at nonlinguistic faculties provides, first of all, for reading special texts. When teaching a common foreign language at non-linguistic faculties in 1-4 semesters, teaching aids and manuals include small fragments from the works of writers, and in 5-8 semesters, students study mainly special texts.

However, for the better knowledge of a foreign language and the development of a common culture, the socio-cultural component is important, which is largely ensured by reading the fiction of the country of the language being studied. When reading stories, novels of the famous writers of the country of the language being studied, students deepen their knowledge of the language, form an artistic taste, they learn to analyze and generalize what is being read, to argue their point of view. That is why home reading remains an important component in acquiring linguistic and cultural knowledge. Home reading texts can come in many styles. Each style is characterized by its own characteristics. For home reading classes and the subsequent development of speech practice, it is advisable to choose texts with an entertaining plot, emotional, imaginative and related by themes to the life experience and interests of students.
\end{abstract}

Most modern students do not feel the need for regular reading of fiction, since over the years of study in high school they have developed an artistic taste. Modern students read mostly not fiction, but short informational texts, blogs, etc., since most students spend a lot of time on social networks, read little books (paper / electronic) due to lack of time. Due to the established habit of exchanging short messages on the Internet, young people are increasingly choosing small format texts for reading and communication.

Many teachers consider reading literary texts as an element of the aesthetic development of students. Recently, teachers from different countries of the world have noted that students are not able to convey their feelings and emotions in relation to the read texts. They cannot analyze what was read at the proper level due to the lack of analytical reading skills. A general decline in interest of reading and insufficiently developed verbal communication skills is also noted. The question arises before teachers: in what form and in what volumes students should read fiction at non-linguistic faculties, including classic literature, since it is the language of works of art that makes it possible to know the picture of the world, introducing it to the values of other peoples and promoting intercultural integration.

Reading authentic literary texts by well-known classical writers of the 19th-21st centuries acquires special significance when teaching foreign languages as a means of communication and studying the cultural heritage of the country of the studied language using interactive and sociocultural approaches. The authors of the article offer their experience in teaching how to read fiction (in French) at non-linguistic faculties, the 
Proceedings of SOCIOINT 2020-7th International Conference on Education and Education of Social Sciences, 15-17 June 2020

purpose of which is to develop the habit of students to constantly read and discuss the works of famous writers.

Keywords: reading fiction, non-linguistic faculties, foreign languages, home reading, modern multimedia technologies, analytical reading skills, cultural heritage.

\section{INTRODUCTION}

Teaching foreign languages is aimed at developing communicative competencies, that is, the ability to communicate in a foreign language. The basis of teaching foreign languages is the mastery of 4 competencies, namely oral understanding, written understanding, oral utterance and written utterance, which are not only interconnected, but also complement each other (Council of Europe, 2018). We share the opinion of researchers who consider it necessary and important to use authentic fiction texts in teaching foreign languages, including at non-linguistic faculties (Paran, 2008). It is reading fiction that introduces the characteristics of different cultures, teaches intercultural interaction, and contributes to the formation of creative thinking skills.

\section{LITERATURE REVUE}

The use of authentic fiction for home reading in classes for the study of foreign languages, in particular the French language, contributes to the effective integration of students of non-linguistic faculties into the system of professionally oriented language training and is an indispensable resource for the formation of the whole complex of language skills of students (Hall, 2015). These skills include: genre accessibility of a work of art; content close to the future professional activities of students; the reader's emotional involvement in the issues raised in the text; insignificant degree of linguistic and cultural deviations.

Often an interesting and fascinating piece of text presented in a textbook on the study of a common language (the common French-le français général) may cause a desire to read the whole text, especially if the problems of a literary work are close to the interests of the student. This ensures the emotional involvement of the latter in the context, arouses interest in reading, without which it is impossible to form a "stable positive reaction to reading" (Collie, Slater, 2005). The student's interest in the subject of the text facilitates the formation of the home reading learning process, encourages active participation in the discussion.

A number of researchers propose the comprehensive use of authentic fiction in teaching a foreign language (for example, the French language), combining different approaches, for example, linguistic, contextual, readable and textual. The study of the formal elements of a literary work through careful reading implies the use of a textual approach. When studying the historical and cultural aspects of the text, a contextual approach is used that performs the same functions as the cultural approach (Bloemert, Paran, Jansen, van de Grift, 2017). When using literature as a language resource, linguistic and reader approaches can be undertaken. The language approach involves the use of fiction in teaching a foreign language to form a learning environment characterized by an active position of students in the classroom (Carter, 2015).

Some teachers prefer to use a combination of a language approach with elements of a cultural approach as a teaching method. Teaching a foreign language using a language approach involves such forms of working with text as, for example, using a text review, discussing the read material, filling in gaps in a text, multiple choice questions, making assumptions about how the story will end, writing your own ending of the text, other than the author's, the choice of the most suitable heading for the text, role-playing games according to the plot read (Van, 2009). Such tasks in the language approach meet the needs of students in learning a foreign language, increase their interest in reading fiction in the language being studied and increase their motivation for learning, thereby satisfying the needs of students in learning a foreign language and supporting their interest in studying fiction literature of the studied language. Even when working with fragments of literary works, students not only improve their knowledge of a foreign language, but also develop critical thinking and develop text interpretation skills (Carter, 2015). Of course, the elements of a cultural approach provide an opportunity to introduce students to the characteristics of other cultures that may be different from their own culture and lifestyle (Ter-Minasova, 2015).

The authors of the article believe that it is advisable to use an integrated approach that combines the above approaches when working with authentic literature in classes in a foreign language. Authentic literary texts can be used not only as a language resource, but also as a way to increase the educational level of 
Proceedings of SOCIOINT 2020- 7th International Conference on Education and Education of Social Sciences, 15-17 June 2020

students, make them open to understanding the history and culture of the country of the studied foreign language.

\section{METHODOLOGY AND EXPERIENCE}

The literary text is characterized by some specific features that distinguish it from other texts, as it forms the features of the world view and is capable of evoking emotions. Of course, preference is given to authentic foreign language texts. When working with literary texts for teaching a foreign language, the teacher faces the problem of selecting texts taking into account the lexical and cultural aspects (Duncan, Paran, 2017), as well as questions related to the choice of texts: how to choose literary texts for use in class? What criteria should be followed in your choice? What factors should be considered when choosing texts? What skills will students learn after reading the text? Each teacher can confirm that it is not easy to find texts for reading that take into account the existing knowledge and skills of students, which arouse interest in reading, and comprehensively reflect a foreign language culture. The teacher should analyze the degree of linguistic accessibility of the text, that is, the students' ability to overcome linguistic difficulties in the reading process. An analysis of the text is necessary to identify language deviations - deviations from generally accepted lexical and grammatical norms used by the author of the text as a means of solving artistic problems, to determine the degree to which the text is filled with linguistic and regional information, which constitutes natural background knowledge. For example, when reading a text from classical literature, in which there is an excessive amount of archaisms and complex stylistic constructions, interest in home reading can be reduced. In other words, when selecting original literature in a foreign language, it is necessary to consider its accessibility to the learner, i.e. the time of its creation and the genre chosen by the writer.

As our experience shows, the use of the works of authors of the 20-21 century is most effective in teaching a foreign language, since they are chronologically closer to our time, arouse greater interest of students and encourage them to participate in discussions and express their attitude to the described. It is advisable to find a balance between the texts of classical and modern authors. Important criteria for selecting texts are the correspondence of the lexical complexity of the text to the level of students' language training, as well as the effective interaction between the text and the interest of the reader-student. Our point of view coincides with the point of view of a number of researchers that when selecting texts, it is first of all necessary to pay attention to the linguistic and cultural component of the text (Vigner, 2001). The syntax and vocabulary of the text proposed for home reading should take into account the level of the student. If the proposed text will contain many unfamiliar words and complex grammatical constructions, then the student will not have the desire to read such a text.

An important factor limiting the choice of texts is the socio-cultural reality. Sociocultural reality should not be completely unknown to the reader, since in this case it can cause real difficulties in terms of understanding the plot and interpreting the text. The sociocultural reality of a literary text should allow comparison with the reality of the reader's usual life. For home reading at earlier stages of instruction, works with an exciting plot, for example, detective stories, romance novels, thrillers, are of interest, and at a more advanced stage, work with works by classical authors is possible.

So, in our opinion, the selection criteria for texts include issues close to the interests of the reader, an interesting story based on conflicts of personal and professional life of the characters; stylistic neutrality and modernity of the language, the formation of linguistic, sociocultural and professional competencies. For home reading, it is important not to impose specific texts on students, but to provide students with the opportunity to make their own text choices. In order to interest students in the text chosen by the teacher, it is possible to pre-read the excerpt from the proposed text to students, and they will decide for themselves whether to continue reading the text or not. At the same time, to clarify the range of interests for students before selecting material for home reading, it is advisable to conduct a preliminary survey among students, including the following questions: "How do you feel about reading fiction? Do you often read books? What is your favorite genre? What is your favorite book?, and so on. The teacher can also offer the student a list of books for home reading. Thus, the student himself will be involved in the choice of text, and the teacher must make sure that the selected text is not too complicated and corresponds to the linguistic level of the student.

At the first reading, the student must understand the text as a whole, headings, separate paragraphs and be able to answer questions such as "Who?", "What?", "Where?", "When?", "Why?", etc. At this stage, knowledge of grammar, vocabulary, as well as the content of stable elements characteristic of a particular genre of text allow the reader to better understand the text as a whole (Cuq, Gruca, 2002). To understand the organization of the text, the student searches for keywords in the text, looking at paragraphs and paying attention to logical connectors, formulates hypotheses about the content of the text using headings. As a rule, the teacher offers short stories for this type of reading and articles (Albert, Souchon, 2000). The 
structure of the narrative text (novel, short story, essay) is replete, for example, with descriptions, listings, paraphrases. For descriptive text, from the point of view of stylistics, such figures as comparisons, metaphors, hyperbolas, and connotations are characteristic. In the reasoned text, the author defends the position on a specific issue, building a chain of arguments using logical connectors, thematic vocabulary, connotation, repetition, exaggeration, aimed at enhancing the influence of arguments. The subjectivity of the reasoned text is revealed using the appropriate dictionary, the presence of verbs expressing opinions and the use of certain adverbs (for example, "no doubt, since ..."). Thus, the study of not only special, but also artistic tests helps to teach reasoned statements in a foreign language, the ability to defend one's point of view, which, of course, is a prerequisite for the formation of a future graduate of a non-linguistic faculty.

The next step is in-depth reading, which includes obtaining additional information, a detailed analysis of the main ideas of the text (Tagliante, 1994). Then comes a critical reading, i.e. thorough and detailed reading, the result of which can be a comment on the text (Cuq, Gruca, 2002). Having fully understood the text, the learner expresses his attitude to the text, analyzes it, writes a comment, which helps to consolidate the received knowledge and expansion of existing ones.

When working with such an aspect of teaching a foreign language as home reading, the authors of the article developed a methodological model that includes several stages. At the first stage, an introduction to the topic and familiarization with key vocabulary takes place. After choosing a work for home reading, the teacher prepares a thematic dictionary for students and announces the topic ("Visit the Loire Castles", "Trap", "Lunch at the President", "Fair"). Based on the chosen topic and using the vocabulary suggested by the teacher, students are invited to predict the plot using the appropriate vocabulary. Using their background knowledge, students tell everything that they know about the proposed topic. For example, students reading the Eygletière Family trilogy by Henri Troyat will be offered preliminary study cards with vocabulary on topics such as family relationships, family problems, emotional and psychological conditions, adolescent problems, generational problems, and the topic "Vacations visiting the Garnel family" can be offered. The second stage is acquaintance with the name of the book and the author. Students by the title get acquainted with the main theme of the selected text / work and suggest the possible content of the text. At the third stage, an understanding of the content of the read is developed. Our experience shows that the use of open and closed questions to control what is read is very effective and significantly saves the classroom time of checking the assimilation of the read material. Closed questions (true and false) are aimed at understanding the general content of the text read and suggest a short answer. An open question requires a detailed answer and shows the extent to which a certain fact or statement helps the student explain and comment on the text read. Students are invited to give the main characteristics of the text they have read, to determine to which literary genre this or that text belongs. When reading at home, it is important to pay sufficient attention to the general understanding of the text and not always concentrate on the details.

At the next stage, as you read the work, special attention is paid to the study of new words and grammatical structures by students. To work with vocabulary, the authors offer various tasks for the selection and study of synonyms, antonyms, language equivalents, as well as compiling a dictionary. To learn and consolidate the new vocabulary and grammatical structures, the teacher can offer students a list of keywords, using which they can formulate their version of the development of events, and then compare it with the version of the author. To check the correct understanding of a particular word, expression, phrase, text fragment, the authors of the article suggest using paraphrases, periphrases, matching synonyms taking into account the context, etc. For teaching reasoned statements based on the read text, the authors of the article consider it effective, along with others, to propose a task on filling out tables using quotes from the text read, confirming (arguments "for") or refuting (arguments "against") a particular statement, fact, etc. In addition to answering questions to control understanding of the text in home reading, students are offered creative assignments that stimulate their creativity. At the final lesson in home reading, role-playing games prepared by students, thematic discussions and presentations, reasoned expression of their opinion on what they read are mandatory. Written control of a creative nature is carried out by the authors in the form of tasks for students to write a letter to the heroes of a work, write an advertising or critical article about a read book for the media, come up with the other end of the text, etc. For home reading in senior courses, there may be suggested a certain number of books to be read during independent reading by different students, followed by a discussion of what they read in class. Of course, these days home reading instruction is hard to imagine without the use of the internet. After reading a fragment of the book and becoming interested in the plot, the student can easily, quickly and often for free find not only the desired work on the Internet, but also additional information about the author, era, heroes and critical articles about the work itself. Also, the Internet can be used when performing various types of tasks, for example, listening to an audio or video recording of a work and determining the main theme, working out the phonetics, watching the film adaptation of the work, 
followed by sounding of a certain passage / fragment / episode in the classroom.

The final stage of reading a literary text is the compilation of a "Report on Read" or "Reader's Diary". This document is submitted by the student at the end of reading the work (or works) of fiction and contains information on the student's attitude toward reading, lexical and grammatical analysis performed by the student, a list of keywords and expressions, as well as a reasoned essay based on the material read. At the same time, the report notes the difficulties encountered and indicates the dictionaries and information sources that the learner used to understand the read work. The purpose of the report is to support the student's interest in additional reading, expand his vocabulary and horizons, introduce him to the culture and customs of the country of the language being studied, for example, through the works of French-speaking authors.

\section{RESULTS}

The testing of this technique was carried out in the period from 2014 to 2018. In the course of the research, the groups in which the training was carried out using this technique showed higher results in mastering a foreign language. In the final comparison, the indicators were as follows: in a group of non-linguistic students using the methodology after 2 semesters of study, the level of foreign language proficiency is according to the "Common European Framework of Reference for Languages: Learning, Teaching, Assessment" (Council of Europe, 2018) corresponded to B1-68\%, A2-30\%, A1-2\%. At the same time, in groups without applying the methodology of the authors of the article, the results were as follows: $\mathrm{B} 1-21 \%, \mathrm{~A} 2-52 \%, \mathrm{~A} 1-27 \%$, i.e. lower.

Conducting regular classes in home reading and the use of this technique allowed the authors to increase the interest of students in reading, enrich their linguistic and culturological knowledge, and improve the effectiveness of studying a foreign language in non-linguistic faculties. The above methodology has been successfully applied at the non-linguistic faculties of RUDN University, in particular, when teaching French at the Law Institute and at the Faculty of Humanities and Social Sciences.

\section{CONCLUSIONS}

The purpose of home reading is to acquaint students with previously unknown French-speaking authors and their works, to develop and support the interest of non-linguistic faculty students in additional reading of authentic fiction in the studied foreign language, to expand and deepen their vocabulary both in a common foreign language, and foreign language specialties, enrich the horizons of students with additional knowledge of culture, history, customs and traditions of the countries of the language being studied. A literary text has an aesthetic function that a teacher can use by connecting this text with other types of art and thus develop the artistic taste of the student. Therefore, reading authentic literary texts occupies an important place not only in teaching a foreign language (French), but also in shaping the student's personality.

Our experience in teaching French as a foreign language confirms that when teaching French as a foreign language, it is advisable to combine the linguistic approach with the sociocultural, improving the language training of students and causing their interest in reading authentic fiction. The application of the proposed methodology, including the selection of works of art, the system of exercises and creative tasks, the use of modern multimedia technologies, allow to reveal the richness of the language being studied, the multifaceted culture of French-speaking countries, make studying a foreign language interesting for students and contribute to the implementation of foreign language communication in a certain field of activity.

\section{ACKNOWLEDGEMENTS}

The publication was prepared with the support of the RUDN University program 5-100.

\section{REFERENCE LIST}

Albert, M.-C., Souchon, M. (2000). Les textes littéraires en classe de langue. Paris, Hachette.

Bloemert, J., Paran, A., Jansen, E., van de Grift, W. (2017). Students' Perspective on the Benefits of EFL Literature Education. The Language Learning Journal. DOI: 10.1080/09571736.2017.1298149

Carter, R. (2015). Epilogue: Literature and Language Learning in the EFL Classroom. M. Teranishi, Y. Saito, 
K. Wales (eds) Literature and Language Learning in the EFL Classroom. Basingstoke, Palgrave Macmillan.

Collie, J., Slater, S. (2005). Literature in the Language Classroom. Cambridge University Press.

Council of Europe. (2018). Common European Framework of Reference for Languages: Learning, Teaching, Assessment. https://rm.coe.int/cefr-companion-volume-with-new-descriptors-2018/1680787989

Cuq, J.-P., Gruca, I. (2002). Cours de didactique du français langue étrangère et seconde. Presses Universitaires de Grenoble.

Duncan, S., Paran, A. (2017). The Effectiveness of Literature on Acquisition of Language Skills and Intercultural Understanding in the High School Context. London: UCL Institute of Education, University College London.

Hall, G. (2015). Literature in Language Education. New York, Palgrave Macmillan.

Paran, A. (2008). The Role of Literature in Instructed Foreign Language Learning and Teaching: An Evidence-Based Survey. Language Teaching, volume 41 (No 4).

Tagliante, C. (1994). La classe de langue. Paris, Clé International.

Ter-Minasova, S. (2015). Prepodavanie inostrannykh yazykov v sovremennoy Rossii: proshloe, nastoyashchee i budushchee [Teaching Foreign Languages in Contemporary Russia: The Past, Present, and Future]. Molodoy ucheny, (No 15).

Van, T. T.M. (2009). The Relevance of Literary Analysis to Teaching Literature in the EFL Classroom. English Teaching Forum, volume 47( No 3).

Vigner, G. (2001). Obucheniye frantsuzskomu kak vtoromu yazyku [Teaching French as a Second Language]. Paris, Clé International. 